\title{
Zalacca Based Food Industry Development in Karang Asem District Bali Province
}

\author{
I Gusti Bagus Udayana ${ }^{{ }^{*}}$, Ni Made Defy Janurianti ${ }^{1}$, AA Ngurah Mayun Wirajaya ${ }^{1}$, Made \\ Sri Yuliartini ${ }^{1}$, Luh Kartini ${ }^{1}$, Ida Bagus Komang Mahardika ${ }^{1}$, AA. Made Semariyani ${ }^{1}$, I \\ Gede Pasek Mangku ${ }^{1}$, Yohanes Parlindungan Situmeang ${ }^{1}$, I Komang Jiwa Antara ${ }^{1}$, I Gusti \\ Ngurah Agung Pawana ${ }^{1}$, M. Pambudi Nurwantara ${ }^{2}$ \\ ${ }^{1}$ Faculty of Agricultural, Warmadewa University, Indonesia \\ ${ }^{2}$ Faculty of Agriculture. Merdeka University, Madiun, East Java \\ *Email: bagusudayana64@gmail.com
}

\begin{abstract}
The food industry is one of the industries that is growing very rapidly throughout the world, including in Indonesia. Various types of food and beverages with an attractive appearance continue to be produced to increase the aesthetic value and attractiveness of consumers. Food and beverage production processes include the selection of raw materials, food and beverage processing, food and beverage quality testing, packaging to the food and beverage distribution process. Every process that takes place must be controlled so that the final product produced is safe and suitable for consumption by consumers. Zalacca production in Karangasem Regency is very good to be developed into the useful food industry. The development of the zalacca-based food industry can increase added value for the people and zalacca commodities. The results of the study using the Process Hierarchy Analysis methodology show that Chips, Syrups, and Extracts occupy high yields to be developed.
\end{abstract}

Keywords: Agroindustry, Development of Food Industry, Development of zalacca based value-added.

\section{Introduction}

The food industry in Indonesia is increasingly playing a role in the development of the industry and the national economy as a whole. The development of various types of industries that process raw materials originating from the agricultural sector shows that the development of the national food industry is quite meaningful, as evidenced by the large number of new types of food or food that have emerged on the market today, thereby increasing the efforts of food entrepreneurs to improve performance his effort.

The food industry is one of the industries that is growing very rapidly throughout the world, including in Indonesia [1]. Various types of food and drinks with an attractive appearance are always produced to increase the aesthetic value and attractiveness of consumers. Food and beverage production processes include the selection of raw materials, food and beverage processing, food and beverage quality testing, packaging to the food and beverage distribution process. Every process that takes place must be controlled so that the final product produced is safe and suitable for consumption by consumers [2]. To develop the significant food industry, the role of products to be processed into food is not enough based on the quality of the ingredients alone, but also the quantity and continuity of the production of these food commodities must be considered so that the sustainability of the food industry is running properly [3], [4].

The development of zalacca -based food industry is very possible, this is because Bali as one of the world tourism destinations, but for the development of the food industry many things need to be 
considered, including how the production of agricultural commodities which will be used as business materials of the food industry has advantages both in terms of quality, quantity, continuity, and growth, and development that has the identity of these products in several areas in Bali, thus becoming southwest scrambled its well for the consumption of the food industry as well as for fresh consumption [5].

Zalacca food industry is one of the agricultural products that show positive development, but several problems hamper its development, both at the farm level and at the processing level [6]. In this rapid development of tourism, the zalacca fruit trade sector in the Province of Bali remains a potential business type and plays a very strategic role. This is based on the high demand for products produced both for tourism needs and other community needs. The commodity is a product of considerable potential and cultivated by farmers in Bali. In the process of development, there has been a growing of fruit production centers with several locations where during the harvest season it often experiences overproduction so that prices fall [7]. This is compounded by the lack of development of post-harvest handling technology and inadequate support for post-harvest infrastructure, namely the existence of crop losses, causing the damage of fresh agricultural products [8]. In connection with this matter, to increase value-added and diversified products, the processing industry to be one alternative solution worthy of consideration [9]. In the development and existing market opportunities, the food processing industry has good market prospects, but the food entrepreneurs still face obstacles to develop their food industry, including because of the mastery of processing technology, processing infrastructure, capital, and market dominance that are still weak [10]. To design the right solution, all the potentials, prospects and constraints/problems that need to be analyzed comprehensively so that the right strategy can be obtained for that study needs to be conducted on the possibility of developing the zalacca-based food industry [11], [12].

\section{Research Method}

In this research, a system structure that influences the feasibility and strategy of the development of zalacca -based food industry in Bali Province is carried out, as well as identifying and formulating the pattern of interrelationships of influential factors. The activities that will be carried out include: (1) identifying and selecting priority zalacca fruit, (2) mapping the potential and location of zalacca production centers, (3) arranging zalacca fruit industry trees, (4) determining the center of zalacca processing industry, (5) to analyze the business feasibility of primary farmers and the product processing industry, and (6) development strategy based food processing industries bark.

\section{Results and Discussion}

\subsection{Mapping Potential Fruit and Location of Production Centers}

Field activities are in doing is to do a preliminary survey to determine the production potential of commodities as well as the location of food commodities industry-based barking. The survey in doing to some potential areas of fruit featured in Karangasem regency in the village to see the potential for commodity Sibetan bark. The results of the survey of the location of the central position of zalacca fruit production are:

a) Fruit zalacca is located in Banjar Pengawat, Sibetan village with a height of 510 meters above sea level which is an individual owned zalacca plantation developed into agro-zalacca tourism, with the position of $\mathrm{LS} 08^{\circ} 27.013^{\prime}$ and LE $115^{\circ} 31.545^{\prime}$. From the management of agro garden bark, fruits produced are processed into several processed commodities, among others: candied bark, bark pia, coffee bean extract bark, tea of bark, bark dodol, and wine from barking. 
b) Komoditas processed bark that is arrack (alcohol) and coffee bark that is processed products that have been marketed abroad by intermediate traders in the region of Karangasem.

c) In Telaga village, Sibetan village with an altitude of $587 \mathrm{~m}$ above sea level. At location LS $08^{\circ}$ 26.466' and LE $115^{\circ} 31.126^{\prime}$ '. In this region also developed barking, but do not do the further processing of the bark at yield production but sold as fresh fruit. In regions other is in the village Sibetan mostly barked management in production for consumptions like fresh fruit, no more manageable. This is caused by the zalacca processing of food industries becoming constrained by one of them in terms of marketing. The pictures of field activities for zalacca commodity can be seen in the following figure:
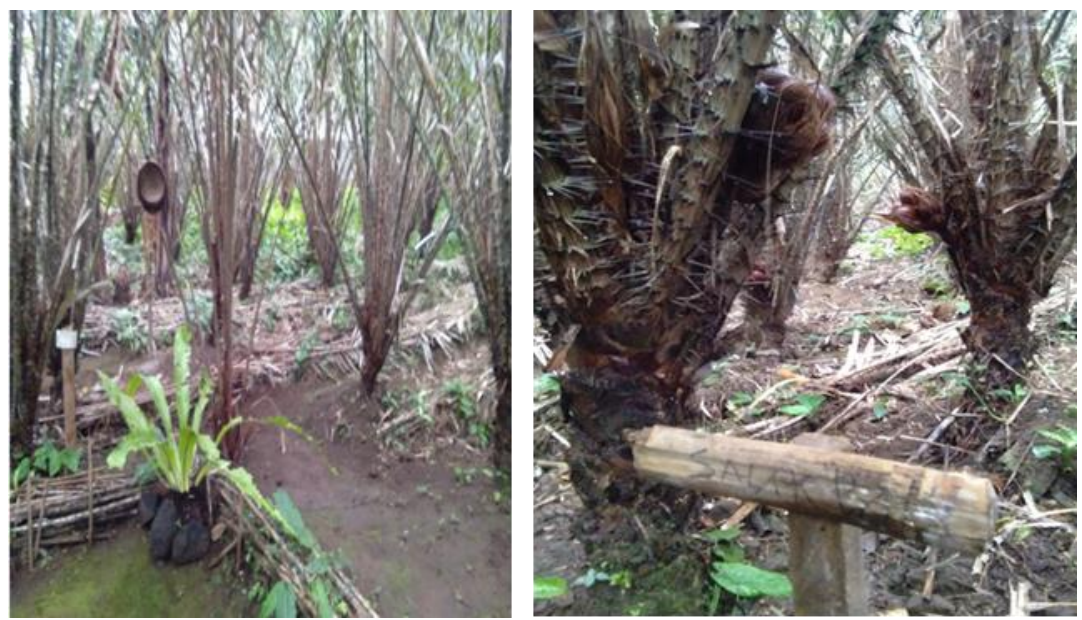

Figure 1

Zalacca Tree in Sibetan Village
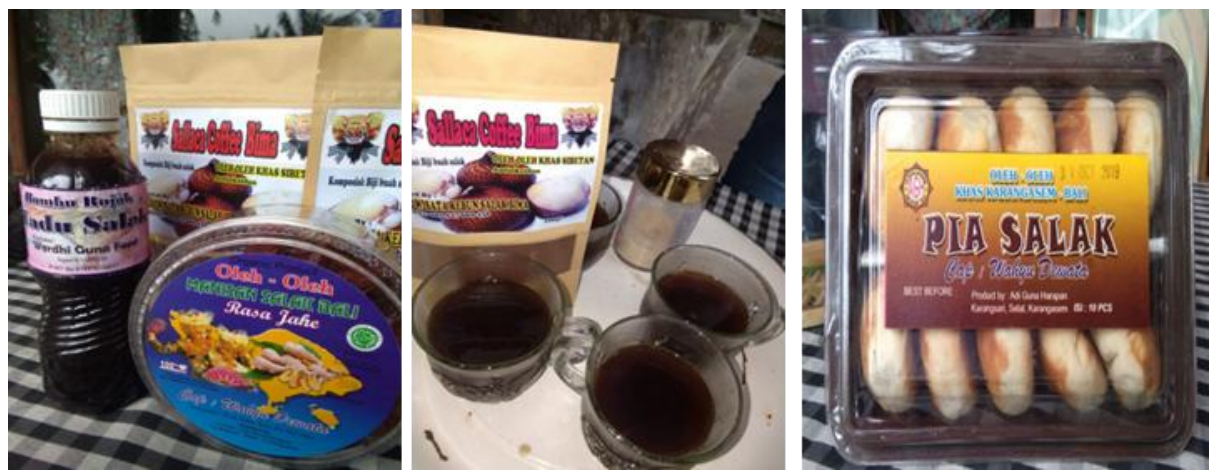

Figure 2

Zalacca processed products

\subsection{Arranging Zalacca Fruit Industry Tree}

An industrial tree is a diagram that illustrates a product derived from a commodity, or the components forming a product. Collected from various sources to see a general picture of the possibilities that can be generated from processing a commodity. The zalacca industry tree in the food industry development activities as follows: Zalacca industry tree consists of 10 processed products that allow it to be developed, namely: Sweets, Chips, Syrups, Extracts, Beverage "Coffee", Firewood, Weaving Thread, Waste, Crafts, and Organic Fertilizers. The flowchart of the tree industry is: 


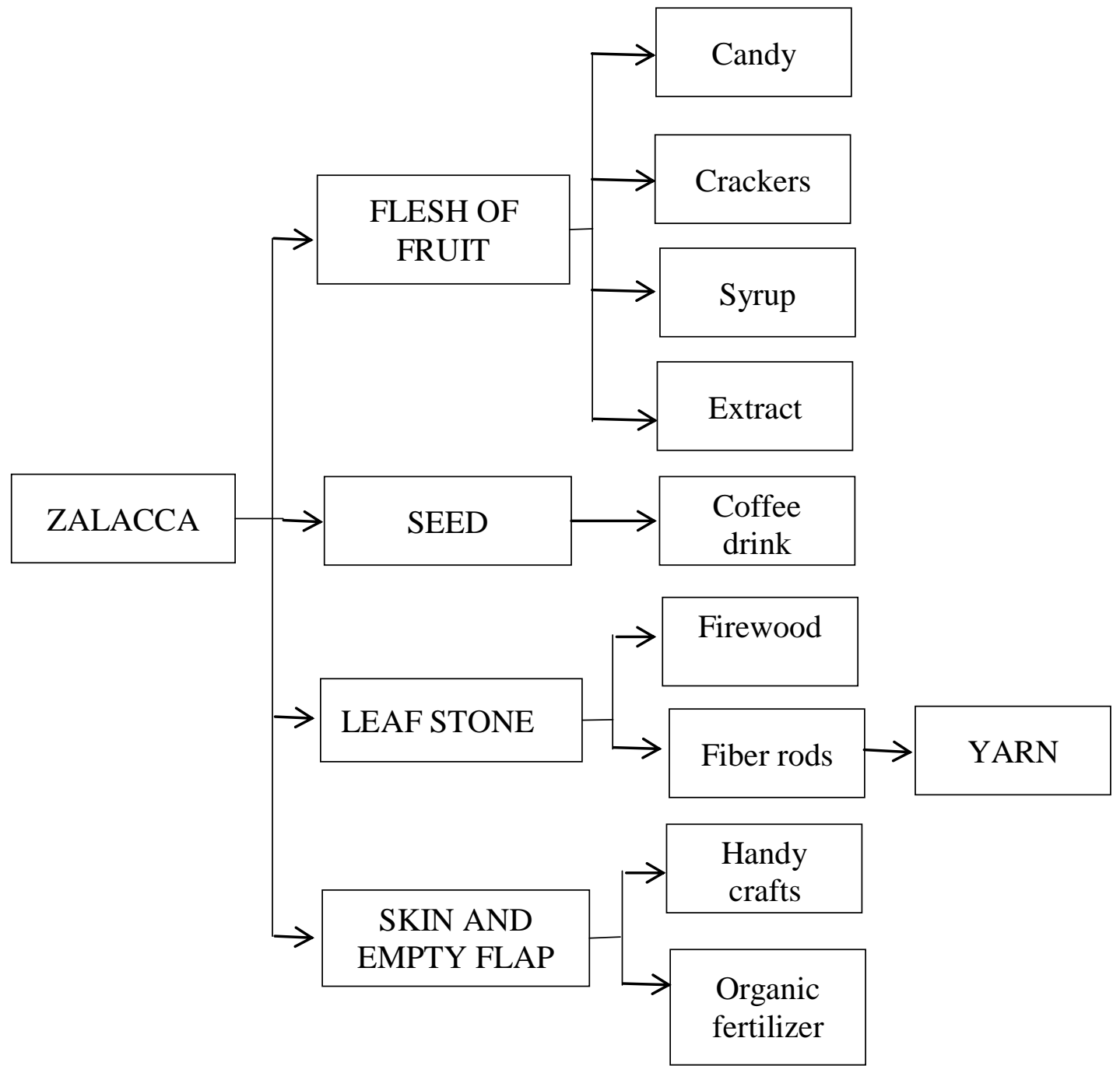

Figure 3

Zalacca industrial tree flow chart

\subsection{Selection of zalacca Fruit Processed Through AHP}

AHP is used in processing questionnaire data that supports the selection of commodity priorities [13]. In the use of this method helps researchers in formulating alternative processed products from the zalacca [14]. Priority weighting revealed the high priority given by stakeholder respondents regarding the product preparation based on the considerations they have, namely:

Observation activities and FGD in the field which are assisted by using a questionnaire are aimed at determining the processed products of zalacca commodities which are considered to have good potential and can be implemented. The results obtained can be seen in Table 1 .

Table 1

Results of the selection of zalacca commodity

\begin{tabular}{lc}
\hline \multicolumn{1}{c}{ Processed Products } & Priority Weight \\
\hline Lollipop & 0.24 \\
Chips & 0.26 \\
Syrup & 0.22 \\
Extract & 0.15 \\
"Coffee" Drink & 0.13 \\
\hline
\end{tabular}


Zalacca processed products such as chips are the highest processed products with a priority weight of 0.26 and the second processed product is sweets. The results of the interviews show that both of these products sell more easily to consumers because they can be accepted by all segments.

\subsection{Arranging the zalacca Fruit Industry Production Process}

The production process is one of the important stages in business. The production process determines the product, stages, production problems, planning equipment, and possible byproducts. Therefore the need for the preparation of a good production process to produce quality products and according to consumers.

a) Zalacca Production Process

The process of zalacca commodity production can be seen in Figure 4.

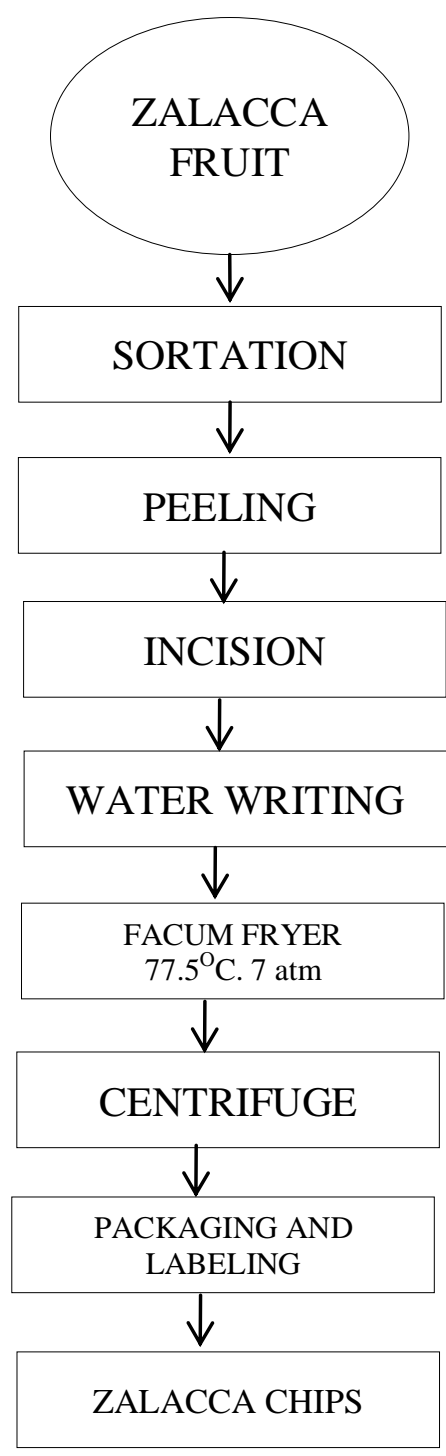

Figure 4

Zalacca chips production process 


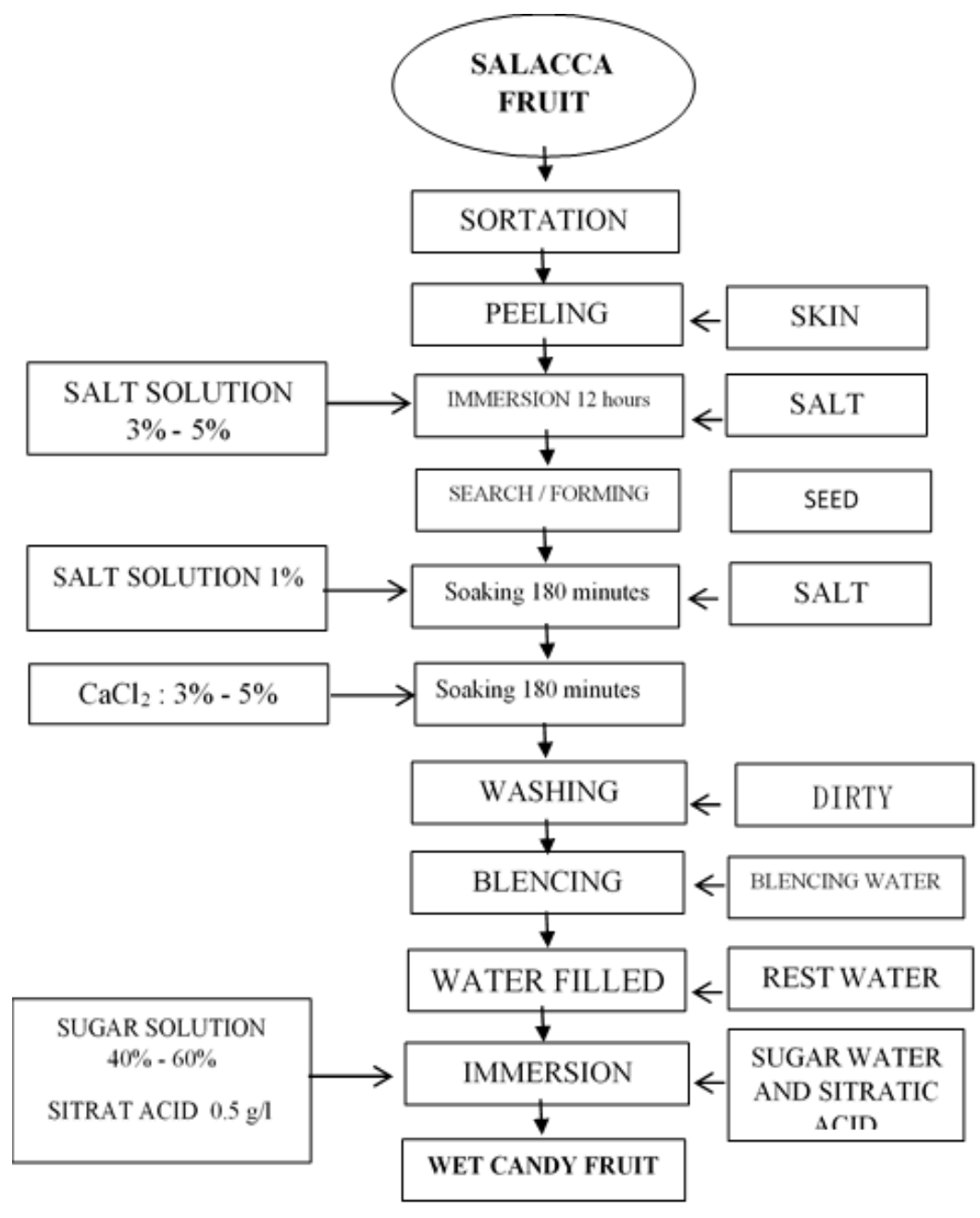

Figure 5

The wet candied fruit production process

The results of the AHP questionnaire and processed found that chips, syrup, and extract are the highest priority values of alternative processing products available. Zalacca syrup is a product that is currently being developed in Telaga Village, Sibetan Village but is still constrained by existing marketing. Weaknesses in marketing cannot be separated from the quality that is owned, the limitations of innovation in the marketing process are also a weakness that is owned by producers in Telaga Hamlet. While zalacca extract can certainly enter various other processing companies such as bread, perfume, beverage, and other food companies.

Table 2

Processed priorities of salak

\begin{tabular}{lc}
\hline Salacca Processed Products & $\begin{array}{c}\text { Processed Priority } \\
\text { Value }\end{array}$ \\
\hline Lollipop & 0.127 \\
Chips & 0.264 \\
Syrup & 0.201 \\
Extract & 0.184 \\
"Coffee" Drink & 0.076 \\
Yarn & 0.039 \\
Handicrafts & 0.066 \\
Organic fertilizer & 0.043 \\
\hline
\end{tabular}



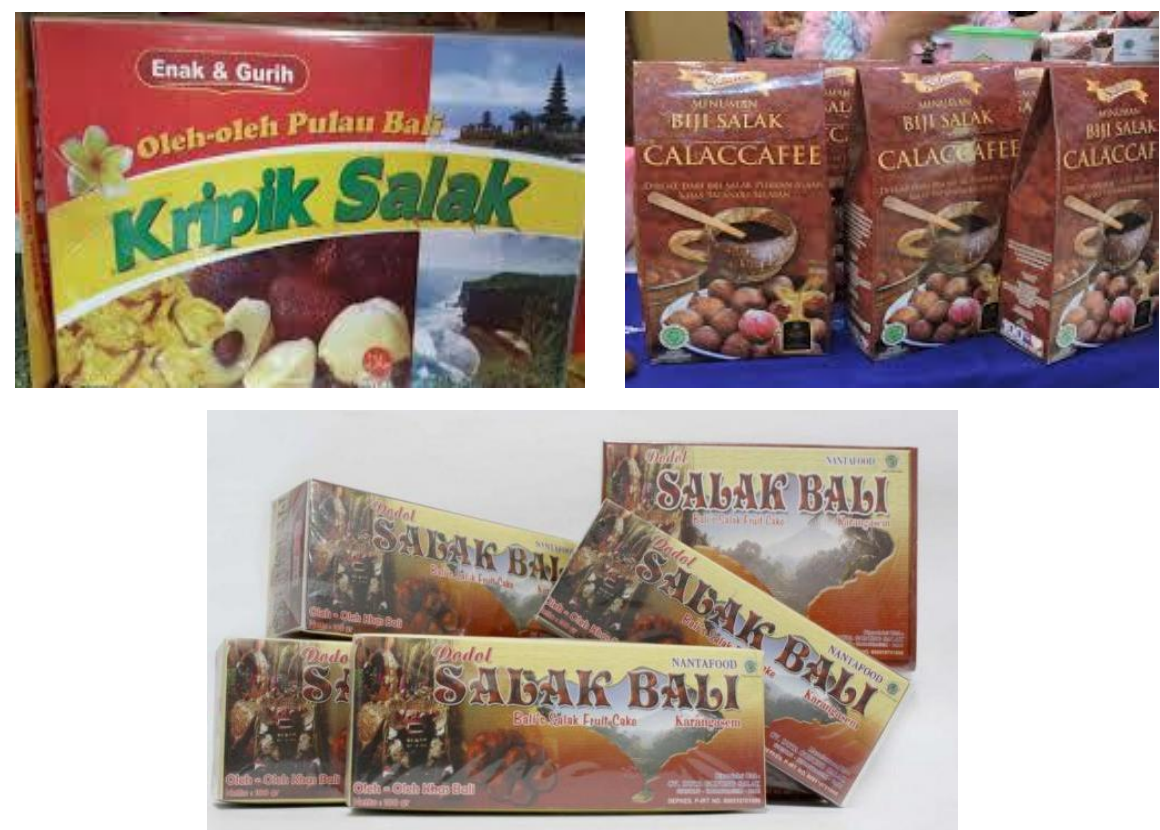

Figure 6

Existing processed zalacca into chips, extracts, and syrup

\section{Conclusion}

Results Obtained a questionnaire and processed AHP that chips, syrup, and extract the highest priority value of alternative processing of existing products. Zalacca syrup is a product that is currently being developed in Telaga Village, Sibetan Village but is still constrained by existing marketing. Weaknesses in marketing cannot be separated from the quality that is owned, the limitations of innovation in the marketing process are also a weakness that is owned by producers in Telaga Hamlet. While zalacca extract can certainly enter various other processing companies such as bread, perfume, beverage, and other food companies.

\section{References}

[1] Amalia D C \& Candrika D. (2011). Corporation strategies for small industries development case study: CV. Mimosabi Handmade Shoes. J Integra 1(2): 175-190.

[2] Amalia S, Rizal S \& Agus M. (2012). Formulation of strategies to increase sheep production CV. Mitra Tani Farm, Ciampea Bogor. J Management \& Agribusiness 9 (2): 77-85.

[3] Arminsyurita (2014). Analysis of marketing strategies for mushroom jaya mushroom. J Scientific Administrative Science 6 (2), 156-168.

[4] Asmarantaka R W, Atmakusuma J, Muflikh Y N, \& Rosiana N. (2017). The concept of agribusiness marketing: an economic and management approach. J Agribusiness Indonesia 5 (2): 143-164.

[5] Harisudin M. (2013). Mapping and development strategy of tempeh agroindustry in Bojonegoro District, East Java. J Agricultural Industrial Technology 23 (2), 120-128.

[6] Massiani R, Sudira P, Mawardi M \& Darwanto D H (2013). The development strategy of agroindustry based on integrated farming systems at tidal swamp areas (A Case Study for Pulang Pisau District, Central Kalimantan Province) J Agritech 33 (2): 234-243.

[7] Morgan R \& Hunt S. (1994). The Commitment-Trust Theory of Relationship Marketing. J Marketing 58 (3): $20-38$

[8] Meky S, Irianto S A, Anjelus I D \& Michael B. (2017). Prime Potency of Agriculture Commodities on Highland of Arfak Mountains Regency, West Papua. Indonesian Agricultural Science Journal (JIPI). 22 (3): 141-146.

[9] Setyowati N W. (2015). The influence of the external and internal environment on competitive advantages in small and medium industries in Bandung, West Java. ESSENTIAL A Business and Management 5 (1), 9-26. 
[10] Udayana I G B. (2017). Marketing strategies arabica coffee with information technology in Kintamani District Bangli. International research journal of engineering, IT \& scientific research, 3(3), 93-102.

[11] Qilang S Q, Muhammad F \& Daryanto H K S. (2017). Analysis of Factors in the Export of Indonesian Agricultural Products to Underdeveloped Countries. Indonesian Agribusiness Journal. 5 (1): 1-10.

[12] Udayana I G B. (2015). Model Development Industrial Cluster Coffee Arabica in The District Bangli, Province of Bali. International Journal on Advanced Science, Engineering and Information Technology, 5(4), 294-297.

[13] Ameri A. (2013). Application of the Analytic Hierarchy Process (AHP) for Prioritize of Concrete Pavement. Global Journal of human social science interdisciplinary, 13(3), 19-28.

[14] Punti M, Hermanto S, Manuwoto M. (2014). Application of Analytical Hierarchy Process (Ahp) in Determining the Priority Scale of Road Operations in Cibinong District, Bogor Regency. Journal of Regional Development Management. 6 (2), 1-12 